\title{
PŘEHLED AKTUÁLNÍ JUDIKATURY I/2019
}

\author{
DOMINIKA GALAJDOVÁ, FRANTIŠEK KASL, IVANA KUDLÁČKOVÁ, \\ PAVEL LOUTOCKÝ, JAKUB MÍŠEK, TEREZA NOVOTNÁ, JAN \\ SVOBODA, JAN ZIBNER, VERONIKA ŽOLNERČÍKOVÁ
}

\section{ÚSTAVNÍ SOUD ZAMÍTL NÁVRH NA ZRUŠENÍ PRÁVNÍ ÚPRAVY DATA RETENTION}

Soud: $\quad$ Ústavní soud

Věc: $\quad$ Pl. ÚS 45/17

Datum: $\quad$ 14. 5. 2019

Dostupnost: nalus.usoud.cz

Návrh skupiny poslanců směřoval na zrušení povinností preventivního shromažd’ování provozních a lokalizačních údajů ze strany poskytovatelů telekomunikačních služeb ${ }^{1}$ a možností jejich následného poskytnutí příslušným orgánům př̀ sledování veřejných zájmů na bezpečnosti a obraně státu, ochraně osob a majetku před trestnou činností, pátráním po osobách a dohledu nad kapitálovým trhem. ${ }^{2,3} \mathrm{~V}$ tomto směru se jedná o další fázi soudního přezkumu proporcionality právní úpravy plošného a nevýběrového uchovávání údajů ve vztahu k právu na soukromí a zachování tajemství zpráv. ${ }^{4}$

\footnotetext{
§ 97 odst. 3 a 4 zákona č. 127/2005 Sb., o elektronických komunikacích na základě změn zavedených zákonem č. 273/2012 Sb.

2 § 88a zákona č. 141/1961 Sb., o trestním řízení soudním, na základě změn zavedených zákonem č. 273/2012 Sb; § 68 odst. 2; § 71 písm. a) zákona č. 273/2008 Sb., o Policii České republiky a vyhláška č. 357/2012 Sb., o uchování, předávání a likvidaci provozních a lokalizačních údajů.

3 Bod 2 anotovaného nálezu.
} 
K návrhu se vyjádřily instituce vyzvané Ústavním soudem. Poslanecká sněmovna a Senát ve svém vyjádření pouze popsaly průběh přijímání napadené právní úpravy. ${ }^{5}$ Ministerstvo průmyslu a obchodu označilo úpravu za vyváženou a vyhovující, což podpořilo sdělením Úřadu pro ochranu osobních údajů z doby přijímání předmětné úpravy. ${ }^{6}$ Vláda považovala českou právní úpravu za prísnou a v souladu s požadavky formulovanými SDEU. ${ }^{7}$ Nejvyšší státní zastupitelství zdưraznilo, že přístup k údajům je pro směr a průběh trestního řízení určující, ${ }^{8}$ vnímalo však nedostatečnost úpravy zákona o Policii ČR. ${ }^{9}$ Úřad pro ochranu osobních údajů se ve svém vyjádření ztotožnil $s$ výtkami skupiny navrhovatelů vůči napadeným ustanovením. ${ }^{10}$ Ústavní soud poměrně netradičně nařídil ve věci veřejné ústní jednání, na kterém vyslechl zástupce odborné veřejnosti a praxe. ${ }^{11} \mathrm{Za}$ hlavní výstupy lze označit informace, že se úprava nevymyká evropskému standardu; že přistup $\mathrm{k}$ údajům by případně orgány získaly jinými právními prostředky; že jde spíše o „startovací“ či podpưrné důkazy v poměrně malém počtu trestních řízení; že $\mathrm{v}$ režimu § 88a trestního řádu $\mathrm{k}$ přístupu dochází výhradně skrze Útvar zvláštních činností; a že dosud nebylo v této souvislosti odhaleno žádné systémové selhání. ${ }^{12}$

Ústavní soud neshledal nedostatky v legislativním procesu přijímání napadené právní právy. ${ }^{13} \mathrm{~V}$ rámci meritorního přezkumu nejprve shrnul obecná východiska konfliktu právní úpravy s ústavně garantovaným

\footnotetext{
4 Ústavní soud se k problematice obsáhle vyjádřil v nálezu ze dne 22. 3. 2011, sp. zn. Pl. ÚS 24/10, a nálezu ze dne 20.12.2011, sp. zn. Pl. ÚS 24/11. Relevantní jsou též rozsudky Soudního dvora Evropské unie ve spojených věcech C-293/12 a C-594/12 ze dne 8.4.2014, Digital Rights Ireland, a ve spojených věcech C-203/15 a C-698/15 ze dne 21.12.2016, Tele2 Sverige.

5 Bod 16 anotovaného nálezu.

6 Bod 20 anotovaného nálezu.

7 Bod 21 anotovaného nálezu.

8 Bod 28 anotovaného nálezu.

9 Bod 29 anotovaného nálezu.

${ }^{10}$ Bod 30 anotovaného nálezu.

11 Bod 33 anotovaného nálezu.

12 Body 34-42 anotovaného nálezu.

${ }^{13}$ Bod 43 anotovaného nálezu.
} 
právem na ochranu soukromí. ${ }^{14}$ Zmínil též vázanost unijním právem a relevantní judikaturou SDEU, která byla následně shrnuta. ${ }^{15}$ Ústavněprávní přezkum pak rozdělil do dvou částí. $V$ první části se zabýval obecnou přípustností plošného, neadresného a preventivního shromaždování a uchovávání dat $\mathrm{v}$ napadeném rozsahu. ${ }^{16}$ Ústavní soud $\mathrm{v}$ tomto směru konstatoval, že s ohledem na technologický vývoj a postup dopadu ICT na společnost nemůže nyní konstatovat explicitní nepřiměřenost data retention, pokud k ní nedospěl ani v podmínkách roku 2011. ${ }^{17}$ Nadto dovodil, že $\mathrm{z}$ hlediska transparentnosti postupu orgánů veřejné moci představuje právní úprava data retention „menší zlo“ než nabízející se alternativy, které by zaujaly její místo. ${ }^{18} \mathrm{~V}$ druhé části pak Ústavní soud posuzoval přiměřenost podmínek a záruk ochrany, jakož i vhodnost vymezení okruhu orgánů oprávněných $\mathrm{k}$ přístupu. ${ }^{19} \mathrm{Na}$ podmínky uchovávání byl aplikován třístupňový test proporcionality, přičemž v prvním kroku Ústavní soud shledal, že silný veřejný zájem naplňuje požadavek legitimního cíle ${ }^{20} \mathrm{a}$ absence skutečného ekvivalentu prokazuje potřebnost úpravy. ${ }^{21}$ Ve vztahu $\mathrm{k}$ proporcionalitě $\mathrm{v}$ užším slova smyslu Ústavní soud konstatoval, že retenční doba 6 měsíců není nepřiměřená sledovanému cíli ${ }^{22}$ a že právní řád poskytuje dostatek záruk proti zneužití uchovávaných údajů. ${ }^{23}$ Ohledně podmínek přistupu $\mathrm{v}$ trestním řízení Ústavní soud dovodil přijatelnost úpravy ve všech zkoumaných ohledech: co do rozsahu přípustného využití, $^{24}$ přísnosti podmínek přístupu ${ }^{25}$ i procesních záruk na obranu dotčené

${ }^{14}$ Body 46-52 anotovaného nálezu s odkazem na předchozí výklad v nálezu sp. zn. Pl. ÚS 24/10, bodech 26-40.

15 Body 53-62 anotovaného nálezu.

${ }^{16}$ Bod 64 anotovaného nálezu.

${ }^{17}$ Bod 76 anotovaného nálezu s odkazem na nález sp. zn. Pl. ÚS 24/10.

18 Bod 78 anotovaného nálezu.

19 Bod 65 anotovaného nálezu.

${ }^{20}$ Body 83-85 anotovaného nálezu.

${ }^{21}$ Bod 86 anotovaného nálezu.

${ }^{22}$ Bod 92 anotovaného nálezu.

${ }^{23}$ Bod 97 anotovaného nálezu.

${ }^{24}$ Body 100-106 a 109 anotovaného nálezu.

${ }^{25}$ Body 107 a 109 anotovaného nálezu. 
osoby. ${ }^{26}$ Obdobné závěry učinil i ohledně dalších využití údajů na základě zákona o Policii ČR, které nebyly Ústavním soudem posuzovány v předchozích řízeních. ${ }^{27}$ Přiměřenost přístupu dalších orgánư ${ }^{28}$ Ústavní soud nezkoumal, jelikož nebyla napadena př́slušná zvláštní právní úprava, obecně však konstatoval legitimnost daných cílů. ${ }^{29}$ Na závěr soud konstatoval, že ani prováděcí vyhláška nevybočuje z mezí ústavnosti, jelikož oproti předchozí reaguje na požadavky formulované v nálezech Pl. ÚS 24/10 a Pl. ÚS $24 / 11 .^{30}$

Ústavní soud při svém posouzení přihlédl ke kontextu současného společenského i technologického vývoje i ke změně právní úpravy od posledního posouzení její ústavnosti. Shledal, že ji lze ve všech napadených směrech vyložit ústavně konformním způsobem, a proto návrh zamítl. ${ }^{31}$

Soudkyně Šimáčková zaujala ve věci odlišné stanovisko, ve kterém se postavila proti nosným závěrům pléna. Zdůraznila, že dané údaje umožňují sestavit podrobný osobní a komunikační profil jednotlivce ${ }^{32}$ a že je na místě brát v potaz související požadavky ochrany osobních údajü. ${ }^{33}$ Domnívá se, že napadená právní úprava neposkytuje ucelený a koherentní systém záruk $^{34} \mathrm{i}$ tím, že nestanovuje konkrétní ochranná technická opatř̌ení. ${ }^{35}$ Nesouhlasí dále s tím, že neexistuje alternativa, přičemž odkazuje na režimy zkráceného uchovávání a kombinace s postupy data freeze, které jsou přítomné v Německu či na Slovensku. ${ }^{36}$ Odmítá tedy, že by zrušení právní úpravy vedlo k chaosu či „legislativnímu stínu“, pokud by Ústavní soud svým nálezem podpořil naléhavou potřebu přijetí úpravy nové a stanovil dostatečně

\footnotetext{
${ }^{26}$ Body 108 a 109 anotovaného nálezu.

27 Body 110-117 anotovaného nálezu.

28 Bezpečnostní informační služby, Vojenského zpravodajství a České národní banky.

29 Body 118 a 119 anotovaného nálezu.

30 Bod 121 anotovaného nálezu.

31 Bod 129 anotovaného nálezu.

32 Bod 2 odlišného stanoviska.

33 Body 5-7 odlišného stanoviska.

34 Bod 3 odlišného stanoviska.

35 Bod 8 odlišného stanoviska.

36 Bod 11 odlišného stanoviska.
} 
dlouhý odklad vykonatelnosti. ${ }^{37} \mathrm{Na}$ závěr pak varuje před data retention jako před rizikem pro demokracii jako takovou. ${ }^{38}$

Autor: FK

\section{CO DĚTI? MAJÍ SI KDE HRÁT? OPĚT PŘED SOUDEM}

Soud:

Vrchní soud v Praze

Věc:

5 Co 16/2018-341

Datum:

8. 4.2019

Dostupnost: získáno na základě zákona č. 106/1999 Sb., o svobodném přístupu k informacím

Žalobce je autorem písně „Až“ interpretované hudební skupinou Katapult. Strana zelených coby žalovaná se rozhodla užít část textu této písně, resp. její refrén v rozsahu „Co děti? Mají si kde hrát?“ v rámci volební kampaně $\mathrm{v}$ roce 2010 , nicméně bez žalobcova svolení $\mathrm{k}$ užití díla.

Žalobce proto vyzval žalovanou k upuštění od jednání, ovšem bezvýsledně. Rozhodl se proto žalovat Stranu zelených za neoprávněné užití ve smyslu § 12 odst. 1 a $\S 40$ zákona č. 121/2000 Sb., autorského zákona, a za zásah do osobnostních práv ve smyslu § 11 daného zákona. Stejně tak žalobce namítal vzbuzování mylného dojmu, že je s žalovanou politickou stranou jakkoliv spojen. Městský soud v Praze v návaznosti na to (a po připomenutí již jednoho rozhodnutí v dané věci se stejným výsledkem) ${ }^{39}$ rozhodl tak, že uložil žalované mimo jiné povinnost zaplatit žalobci 350.000,Kč coby dvojnásobek obvyklé výše licenční odměny. ${ }^{40}$ Žalovaná se proti rozhodnutí odvolala, a to zejména s argumentem špatného znaleckého posouzení v dané věci.

37 Bod 14 odlišného stanoviska.

38 Body 16 a 17 odlišného stanoviska.

39 Konkrétně se jedná o rozsudek Městského soudu v Praze ze dne 20. 8. 2014, č. j. 34 C 171/2010-129. Spor se poté přesunul k Vrchnímu soudu v Praze (srov. rozsudek Vrchní soudu v Praze ze dne 6. 10. 2015, č. j. 5 Co 2/2015-163) a skrze dovolání až k Nejvyššímu soudu (srov. usnesení Nejvyššího soudu České republiky ze dne 31. 8. 2016, č. j. 30 Cdo 733/2016-209), který dovolání odmítl.

40 Stalo se tak rozsudkem Městského soudu v Praze ze dne 20. 12. 2017, č. j. 34 C 171/2010294. 
Vrchní soud v Praze jako odvolací stupeň zejména připomněl své předcházející rozhodnutí v dané věci a zhodnotil kvalitativní zlepšení počínání soudu prvního stupně při zkoumání obvyklé výše licenční odměny. ${ }^{41}$ Soud se též vyjádřil k odborným kvalitám zvolených znalců a jejich odbornosti, jakož i objektivnosti s ohledem na blízký vztah směrem k žalobci, v čemž neshledal závady. ${ }^{42} \mathrm{~V}$ další části soud už jen podrobně rozebral výši nákladů řízení a náhrady za právní zastoupení v dané věci. ${ }^{43}$

Vrchní soud proto ve výsledku potvrdil rozsudek soudu prvního stupně a pouze upravil výši náhrady nákladů řízení.

Spor o skladbu „Až“ se vede již od roku 2010 a v nejbližší době nejspíš nelze očekávat jeho ukončení, zejména s ohledem na minulý vývoj. Vrchní soud tentokrát následoval argumentační linii předchozího stupně a potvrdil zásah do práv žalobce. Bohužel k povaze refrénu coby autorskoprávně relevantní části díla se soud vícero nevyjádřil, ačkoliv by mohlo být zajímavé sledovat argumentaci zejména v kontextu případu Svěrák vs. Bauhaus ${ }^{44}$.

Autor: JZ

\section{ZÁSAH DO SOUKROMÍ NA WEBU ČASOPISU}

Soud:

Městský soud v Praze

Věc:

58 Co 286/2017-465

Datum:

31. 1.2019

Dostupnost: justice.cz

V původním sporu se žalobce domáhal u soudu žalobou na ochranu osobnosti zdržení se šíření informací o své osobě a rodině, stáhnutí těchto

\footnotetext{
41 Bod 9 anotovaného rozhodnutí.

42 Tamtéž.

43 Bod 11 a násl. anotovaného rozhodnutí.

44 Srov. rozsudek Krajského soudu v Brně ze dne 16. 12. 2005, č.j. 23 C 22/2005-58; rozsudek Vrchního soudu v Olomouci ze dne 13. 9. 2006, č.j. 1 Co 64/2006-93; rozsudek Nejvyššího soudu ze dne 30. 4. 2007, sp. zn. 30 Cdo 739/2007; opětovně potom rozsudek Krajského soudu v Brně ze dne 15. 2. 2010, sp. zn. 23 C 61/2007; rozsudek Vrchního soudu v Olomouci ze dne 1. 9. 2010, č.j. 1 Co 126/2010-326; usnesení Nejvyššího soudu ze dne 29. 3. 2012, sp. zn. 30 Cdo 60/2011.
} 
informací z webových stránek žalované a uhrazení způsobené nemajetkové újmy v penězích. ${ }^{45}$

Obvodní soud v Praze v prvním stupni rozhodl o stažení informací a zpráv z webu a také o nahrazení nemajetkové újmy, nicméně v nižší výši, než žalobce navrhoval. ${ }^{46}$ Proti tomuto rozhodnutí se žalobce i žalovaná odvolali, nebyl však napaden výrok o stažení informací z webových stránek žalované, a proto ten jediný nabyl právní moci. Městský soud v Praze o odvolání obou stran rozhodl tak, že snížil žalovanou výši náhrady nemajetkové újmy přiznanou žalobci a potvrdil stažení a další nešíření informací o žalobci. ${ }^{47}$ Proti tomuto rozhodnutí podaly obě strany dovolání k Nejvyššímu soudu. Ten dovolání žalované odmítl. Odmítl též část dovolání žalobce, nicméně v části snižující výši nemajetkové újmy rozhodnutí je zrušil a vrátil odvolacímu soudu zpět k projednání. ${ }^{48}$ Odvolací soud měl tedy znovu rozhodnout o výši přiznané nemajetkové újmy.

Z tohoto důvodu se Městský soud zabýval otázkou, zda je náhrada nemajetkové újmy ve výši 375.000,- Kč pro dva dospělé žalobce a 75.000,- Kč pro dva nezletilé žalobce dostatečně přiměřená ve vztahu ke způsobené újmě. ${ }^{49}$

Městský soud se zabýval téměř výhradně otázkou výše přiměřené náhrady nemajetkové újmy. $Z$ toho důvodu citoval dvě předchozí rozhodnutí zejména Nejvyššího soudu ve věci výše náhrady nemajetkové újmy v difamačních případech, kde byly informace zveřejněny $\mathrm{v}$ online denících. ${ }^{50}$ Městský soud zohlednil zejména proporcionalitu mezi čteností a počtem zhlédnutí jednotlivých článků, průměrnými počty návštěv webových stránek jednotlivých deníků a k tomu přiznaných výší nemajetkových náhrad ve zmíněných př́padech. ${ }^{51}$ Zabýval se mimo to také různými částkami

45 Bod 1 anotovaného rozhodnutí.

46 Bod 3 anotovaného rozhodnutí.

47 Bod 11 anotovaného rozhodnutí.

48 Body 13 až 15 anotovaného rozhodnutí.

49 Bod 46 anotovaného rozhodnutí.

50 Srov. rozhodnutí Nejvyššího soudu ze dne 11. 8. 2018, sp. zn. 30 Cdo 3062/2018, a rozhodnutí Městského soudu v Praze ze dne 17. 9. 2018, č. j. 22 Co 91/2018-370.

51 Body 53 až 56 anotovaného rozhodnutí. 
přiznanými dospělým žalobcům a dětem, kde u nezletilých žalobců uvedl, že právě pro jejich nezletilost je zde klíčový již pravomocný zdržovací nárok, kdežto relutární náhrada je teprve doplňkovým zadostiučiněním, proto částky mohou být nižší ( $\mathrm{v}$ tomto př́ípadě dokonce několikrát). ${ }^{52}$

Na základě uvedených předchozích případů a související argumentace nakonec soud konstatoval zmíněné částky plně dostatečnými.

Autorka: TN

\section{ZVEŘEJNĚNÍ OSOBNÍCH ÚDAJŮ ADVOKÁTA V DATABÁZI JUDIKATURY}

Soud:

Krajský soud v Brně

Věc:

31 A 68/2018-177

Datum:

7. 11.2018

Dostupnost:

nssoud.cz

Žalobce, advokát, se žalobou ze dne 24. 5. $2018^{53}$ domáhal ochrany před nezákonným zásahem do svých práv ze strany Nejvyššího správního soudu. Nezákonný zásah spatřoval žalobce ve zveřejňování osobních údajů v dostupné databázi judikatury v rámci publikování soudních rozhodnutí uvádějících údaje o žalobci jakožto o zástupci jedné ze stran v konkrétní věci.

Soud posuzoval, zda výše nastíněné zveřejňování osobních údajů obsažených v rozhodnutích publikovaných postupem podle zákona č. 106/1999 Sb., o svobodném přístupu $\mathrm{k}$ informacím, ${ }^{54,55}$ zapovídá zákonná úprava (zejména v té době účinný zákon č. 101/2000 Sb., o ochraně osobních údajů), potažmo zda je tímto postupem žalobci nepřiměřeně zasahováno do

\footnotetext{
52 Bod 54 anotovaného rozhodnutí.

53 Žaloba byla podána den před účinností nařízení Evropského parlamentu a Rady (EU) 2016/679 ze dne 27. dubna 2016, o ochraně fyzických osob v souvislosti se zpracováním osobních údajů a o volném pohybu těchto údajů a o zrušení směrnice 95/46 ES.

${ }^{54}$ V bodu 15 anotovaného rozhodnutí soud uvedl, že informace ve smyslu zákona o svobodném př́stupu $\mathrm{k}$ informacím mohou být poskytnuty jak na žádost, tak formou zveřejňování anonymizovaných znění rozhodnutí.

55 Body 16, 39 a násl. anotovaného rozhodnutí.
} 
jeho ústavně zaručených lidských práv (zejména práva na soukromý život). ${ }^{56}$ Za žalobcovy osobní údaje přitom soud označil zejména jméno a př́ijmení, adresu jeho sídla, danou právní věc spolu s podrobnou skutkovou a právní kvalifikací věci soudem, argumentaci či uvedení kárné žaloby. ${ }^{57}$

Soud poukázal na to, že je advokát veřejně činnou osobou, když vystupuje $\mathrm{v}$ rámci soudního řízení, přičemž veřejnost soudního rrízení je stanovena Ústavou České republiky. Dále uvedl, že soukromí zástupců účastníků řízení je nutně a legitimně touto zásadou limitováno. ${ }^{58}$ Soud pak označil advokátní činnost související $\mathrm{s}$ věcí projednávanou v konkrétním soudním řízení (byt tato činnost může představovat advokátovy osobní údaje) za veřejnou prezentaci advokáta, a to právě s ohledem na specifický charakter advokátní činnosti. ${ }^{59}$ Vzhledem $\mathrm{k}$ výše uvedenému a k tomu, že advokát svou činností v rámci soudního řízení dobrovolně vystupuje ze svého soukromého prostoru, nepožívají dle soudu tyto projevy advokáta ochranu v rámci práva na soukromý život; to navíc označil soud za zákonem subjektivně předvídatelnou součást výkonu podnikatelské činnosti advokáta. ${ }^{60}$

Ve zveřejnění žalobcových osobních údajů $\mathrm{v}$ databázi judikatury tak soud nespatřil zásah do soukromého života žalobce. ${ }^{61}$ Soud pak neshledal zveřejnění údajů, které se týkaly výkonu advokacie navenek, ani v rozporu s právem na podnikání, ani se zákonem o ochranu osobních údajů ${ }^{62}$ a ani s jinými právními normami. ${ }^{63}$ Žaloba byla proto zamítnuta.

Rozhodnutí je zajímavé zejména proto, že soud označil za osobní údaje širokou škálu informací o činnostech advokáta v rámci soudního řízení.

Autor: JS

\footnotetext{
56 Bod 24 a násl. anotovaného rozhodnutí.

57 Body 23, 36 až 38 anotovaného rozhodnutí.

58 Bod 44 anotovaného rozhodnutí.

59 Bod 46 anotovaného rozhodnutí.

60 Bod 48 anotovaného rozhodnutí.

61 Bod 51 anotovaného rozhodnutí.

62 Bod 43 anotovaného rozhodnutí; k tomu viz také $\S 5$ odst. 2 písm. d) zákona o ochraně osobních údajů.

63 Bod 56 anotovaného rozhodnutí.
} 


\section{PODOBIZNA POLICISTY U VÝPOVĚDI A OSOBNÍ ÚDAJ}

Soud: $\quad$ Soudní dvůr Evropské unie

Věc: $\quad$ C-345/17 (Buivids)

Datum: $\quad$ 14. 2. 2019

Dostupnost: curia.europa.eu

Lotyšský občan, pan Buivids, natočil při přestupkovém řízení, kde podával výpověd', videozáznam, který zachycoval příslušníky policie. Tento videozáznam zveřejnil na platformě Youtube. Lotyšský úřad pro ochranu osobních údajů posoudil toto počínání jako rozporné s příslušnou právní úpravou zejména $\mathrm{z}$ toho důvodu, že pan Buivids subjektům údajů (policistům) neposkytl informace ohledně účelu zpracování osobních údajů a příslušný úřad pro ochranu osobních údajů neinformoval o účelu pořízení předmětného videozáznamu a jeho zveřejnění na internetových stránkách. Úřad mu tak nařídil, aby příslušný videozáznam odstranil.

Případ posuzoval lotyšský Nejvyšší soud, který měl pochybnosti o tom, jestli spadá natočení policistů při výkonu funkce a zveřejnění videozáznamu do působnosti směrnice o ochraně osobních údajů, která byla implementována do lotyšského zákona o ochraně osobních údajů a zdůraznil, že záznam byl pořízen při výkonu veřejné funkce.

Z toho důvodu položil Nejvyšší soud SDEU otázku, jestli spadá dané jednání do působnosti směrnice o ochraně osobních údajů a jestli je nutno tuto směrnici vykládat v tom smyslu, že zmíněné jednání lze považovat za zpracování osobních údajů pro účely žurnalistiky. ${ }^{64}$

Po jednoznačném vymezení rozsahu působnosti směrnice o ochraně osobních údajů SDEU nejprve konstatoval, že zveřejnění daného videozáznamu představuje zcela nebo částečně automatizované zpracování těchto údajů. ${ }^{65} \mathrm{~V}$ daném prrípadě nejsou naplněny podmínky pro to, aby nedošlo k aplikaci právní úpravy obsažené ve směrnici (takovým důvodem je např́klad veřejná bezpečnost, obrana státu či činnost státu v oblasti trestního

\footnotetext{
${ }^{64}$ Bod 27 anotovaného rozhodnutí.

65 Bod 35 anotovaného rozhodnutí.
} 
práva). ${ }^{66}$ Soud tak konstatoval, že výše popsaná činnost spadá do působnosti směrnice a jedná se o zpracovávání osobních údajů. Soud se dále zabýval argumentací, jestli $\mathrm{v}$ takovém případě dochází ke zpracovávání osobních údajů pro účely žurnalistiky. To, že pan Buivids není novinář, ještě samo o sobě nemůže znamenat, že by videozáznam nemohl být považován za pořízený výlučně pro účely žurnalistiky. Na druhou stranu ale ani nelze dovodit, že dané zveřejnění pod tento pojem spadá, jelikož z předchozího řízení nebyl znám účel pořízení takové nahrávky.

Soud na základě dané úvahy tedy uzavřel, že o zpracování osobních údajů pro účely žurnalistiky se tak bude jednat, pokud se ukáže, že účelem pořízení daného záznamu bylo jen zveřejnění a pořízení za účelem zpřístupnění informací, názorů nebo myšlenek veřejnosti, což musí být v rámci daného př́ípadu dále ověřeno. ${ }^{67}$

Toto rozhodnutí je zajímavé především tím, že přináší poměrně širokou možnost výkladu toho, co se rozumí pod zpracování osobních údajů pro účely žurnalistiky a na to navazující chápání svobody projevu. Nadto je zdůrazněna významná role národních soudů a zákonodárců $\mathrm{v}$ tom, kde bude specificky určena konkrétní hranice.

Autor: PL

\section{PRÁVO AKCIONÁŘE NA VYSVĚTLENÍ VS. OCHRANA OSOBNÍCH ÚDAJŮ}

Soud: Krajský soud v Brně

Věc: $\quad 50 \mathrm{Cm} \mathrm{163/2018-68}$

Datum: 4. 2. 2019

Dostupnost: justice.cz

V rámci žaloby se spolek, který je akcionářem žalované akciové společnosti, domáhal vydání rozhodnutí o její povinnosti poskytnout mu informace na základě akcionářova práva na vysvětlení. Šlo o informace o za-

\footnotetext{
${ }^{66}$ Bod 42 anotovaného rozhodnutí.
}

67 Bod 69 anotovaného rozhodnutí. 
městnávaných osobách blízkých členům představenstva, jejich odměnám a právním titulům $\mathrm{k}$ nim za rok $2017 .^{68}$

Předsednictvo společnosti poskytnutí informací v řádném termínu v celém rozsahu odmítlo s odkazem na ustanovení zákoníku práce a obecného nařízení o ochraně osobních údajů. ${ }^{69}$ Spolek se následně nezúčastnil valné hromady a podal předmětnou žalobu ke Krajskému soudu v Brně.

Soud rozhodoval předně na základě ustanovení §§ 357 a 360 zákona č. 90/2012 Sb., o obchodních korporacích vztahujících se k právu akcionáře na vysvětlení a podmínkám pro zahájení řízení před soudem $\mathrm{v}$ případě odmítnutí představenstvem.

Soud spor vyřešil argumentací, že akcionář, který se valné hromady neúčastní, v souladu s $§ 357$ ZOK vysvětlení obdržet nemůže. ${ }^{70}$ Za těchto podmínek pak akcionář nemůže v souladu s $\S 360$ odst. 2 ZOK žádat dozorčí radu o určení, že podmínky pro odmítnutí poskytnutí vysvětlení nenastaly, což je předpokladem práva akcionáře obrátit se na soud dle $\S 360$ odst. 3 $\mathrm{ZOK}^{71} \mathrm{~V}$ dovětku svého posouzení pak soud vyjádřil souhlasný názor s odmítnutím představenstva, tedy že informace o zaměstnaných osobách blízkých členů představenstva a jejich odměnách nemohou být poskytnuty s odkazem na účinnou právní úpravu ochrany osobních údajů. ${ }^{72}$

Soud na základě výše uvedených zjištění žalobu zamítl a rozhodl o náhradě nákladů řízení.

Autor: FK

\footnotetext{
68 Bod 1 anotovaného rozhodnutí.

69 Bod 2 anotovaného rozhodnutí.

70 Bod 15 anotovaného rozhodnutí.

71 Bod 16 anotovaného rozhodnutí.

72 Bod 17 anotovaného rozhodnutí.
} 


\title{
DATA DOPRAVNÍHO PODNIKU HL. M. PRAHY
}

\author{
Soud: $\quad$ Nejvyšší správní soud \\ Věc: $\quad 7$ As $22 / 2018-56$ \\ Datum: $\quad$ 11. 4. 2019 \\ Dostupnost: nssoud.cz
}

Žalobce, datový novinář Jan Cibulka, požadoval po Dopravním podniku hl. $\mathrm{m}$. Prahy poskytnutí vzdáleného přístupu $\mathrm{k}$ datasetu jízdních řádů aktualizovaného $\mathrm{v}$ reálném čase a $\mathrm{k}$ aktuálním strojově čitelným informacím o poloze tramvají a autobusů (systémy DORIS a AUDIS) a to včetně dokumentace těchto rozhraní (metadat). ${ }^{73}$ Žádost byla Dopravním podnikem odmítnuta $\mathrm{z}$ důvodu přítomnosti osobních údajů řidičů dopravních prostředků a toho, že se jedná o informace, které se vztahují výlučně k vnitřním pokynům a personálním předpisům povinného subjektu.

Žalobce se v návaznosti na to obrátil na Městský soud v Praze, který však argumenty Dopravního podniku odmítl a rozhodnutí Dopravního podniku o neposkytnutí informací zrušil. Zejména uvedl, že není pochyb o tom, že stěžovatel má dané informace $\mathrm{k}$ dispozici, a že není možné zdi̊vodňovat odmítnutí žádosti tím, že by úprava systémů znamenala pro povinný subjekt nepřiměřenou zátěž. Stejně tak uvedl, že v daném případě nemůže jít o zpracování osobních údajů, a odmítl rovněž argument, že informace je součástí autorského díla. ${ }^{74}$ Dopravní podnik na uvedený rozsudek zareagoval podáním kasační stížnosti, v níž popsal celou řadu technických problémů, proč nemůže informace poskytovat. ${ }^{75}$ Žalobce ve svém vyjádření uvedl, že stěžovatel technické problémy může snadno překonat, a že skutečný důvod pro neposkytnutí je nevýhodná smlouva s externím dodavatelem systému. ${ }^{76}$

\footnotetext{
73 Odst. 1 anotovaného rozhodnutí.

74 Odst. 5 anotovaného rozhodnutí.

75 Odst. 6-15 anotovaného rozhodnutí.

76 Odst. 16 anotovaného rozhodnutí.
} 
Nejvyšší správní soud se proto zabýval tím, zda byl rozsudek Městského soudu dostatečně odůvodněn, tedy zda je s odkazem na § 64 soudního řádu správního a $\S 157$ odst. 2 občanského soudního řádu přezkoumatelný. ${ }^{77}$ Díky tomu se nedostal $\mathrm{k}$ věcnému přezkumu rozhodnutí.

NSS dospěl k závěru, že rozhodnutí Městského soudu dostatečně odůvodněné není. NSS nekriticky vycházel z informací poskytnutých Dopravním podnikem, aniž by sám přihlédl $\mathrm{k}$ argumentaci žalobce. Upozornil tak Městský soud na řadu bodů, které dle něj byly nedostatečně argumentované. Předně NSS uvedl, že není jasné, zda požadované informace vůbec spadají do působnosti zákona, protože může jít o nově vytvářené informace. ${ }^{78}$ Dalším argumentem NSS bylo, že žádost o „vzdálený přistup“ by mohla být vnímána jako žádost o „vstup do počítačového programu“" ${ }^{\text {“79 }}$. NSS rovněž plně přijal argument Dopravního podniku, že dokumentace je autorskoprávně chráněnou součástí počítačového programu. ${ }^{80}$ Závěrem NSS uvedl, že Městský soud nedostatečně zkoumal rozsah nezbytných úprav, které by stěžovatel musel před poskytnutím informací učinit. ${ }^{81}$

Na základě uvedených argumentů NSS napadené rozhodnutí zrušil a věc vrátil Městskému soudu k projednání.

Autor: JM

77 Odst. 20 anotovaného rozhodnutí.

78 Odst. 23 a 28 anotovaného rozhodnutí; zde je třeba poznamenat, že uvedený argument NSS ukazuje značné nepochopení toho, jak funguje poskytování informací měnících se v reálném čase, což je způsob, který jak evropská směrnice, tak český zákon předvídá, a který předpokládá, že budou poskytovány informace v době žádosti fakticky neexistující.

79 Odst. 27 anotovaného rozhodnutí; na tomto místě je třeba připomenout, že chráněným vyjádřením počítačového programu je jeho zdrojový a strojový kód a nikoli API, které nijak autorskoprávně chráněné není (viz analogicky rozhodnutí SDEU ve věci C-393/09 ze dne 22. 12. 2010, BSA, a C-406/10 ze dne 2. 5. 2012, SAS Institute).

80 Odst. 22 anotovaného rozhodnutí; přes to, že je uvedený argument značně nepřesvědčivý, protože metadata popisující určitý datový formát nejsou autorským dílem a nemohou proto požívat autorskoprávní ochrany, je třeba poznamenat, že i pokud by uvedená dokumentace byla autorskoprávně chráněná, měl NSS připomenout nález Ústavního soudu ze dne 21. 3. 2017, sp. zn. IV.ÚS 3208/16.

81 Odst. 29-30 anotovaného rozhodnutí. 


\section{ROZHODČÍ SOUD HK A AK JAKO POVINNÝ SUBJEKT DLE ZÁKONA Č. 106/1999 SB., O SVOBODNÉM PŘÍSTUPU K INFORMACÍM}

Soud: $\quad$ Nejvyšší správní soud

Věc: $\quad 6$ As $282 / 2018-46$

Datum: $\quad$ 20.2. 2019

Dostupnost: nssoud.cz

Stěžovatel, společnost JERICHO, spol. s r.o., požadoval od žalovaného Rozhodčího soudu při Hospodářské komoře České republiky a Agrární komoře České republiky informace týkající se činnosti této instituce podle zákona č. 106/1999 Sb., o svobodném př́stupu k informacím. Žalovaný odmítl informace poskytnout s odkazem na skutečnost, že dle jeho názoru není povinným subjektem podle zákona č. 106/1999 Sb. ${ }^{82}$ Stěžovatel se bránil správní žalobou u Městského soudu v Praze, který se však ztotožnil s názorem žalovaného a žalobu odmítl. ${ }^{83}$ Stěžovatel následně podal proti rozhodnutí Městského soudu kasační stížnost.

Nejvyšší správní soud se tak zabýval otázkou, zda je žalovaný povinným subjektem ve smyslu § 2 odst. 1 zákona č. 106/1999 Sb.

NSS ve své argumentaci aplikoval test veřejné instituce, jak ho dřive představil Ústavní soud ${ }^{84}$. $\mathrm{V}$ př́ípadě prvního kritéria, kterým je způsob vzniku povinného subjektu, NSS konstatoval veřejnoprávní charakter žalovaného, jehož právní předchůdce vznikl na základě výnosu ministra zahraničního obchodu č. 128/1949. Veřejný charakter vzniku byl pak potvrzen novelizovanou verzí zákona č. 301/1992 Sb., o Hospodářské komoře České republiky a Agrární komoře České republiky. ${ }^{85}$ Tím je naplněn i druhý znak, tedy hledisko zřizovatele žalovaného, kterým je Česká republika. Ve třetím kroku NSS posoudil charakter účelu činnosti žalovaného. Zá-

82 Odst. 1 anotovaného rozhodnutí.

83 Odst. 3-5 anotovaného rozhodnutí.

84 Srov. nález Ústavního soudu ve věci Letiště Praha ze dne 24. 1. 2007, sp. zn. I. ÚS 260/06.

85 Body 28-30 anotovaného rozhodnutí. 
věrem zajímavě vedené argumentace bylo konstatování, že účelem vzniku je zájem zákonodárce na existenci stálého rozhodčího soudu a nikoli pouze řešení sporů mezi stranami na základě jejich smluvní volnosti. ${ }^{86} \mathrm{U}$ čtvrtého znaku, tj. otázky utváření orgánů žalovaného NSS seznal, že i zde je př́tomný veřejný prvek vzhledem $\mathrm{k}$ účasti orgánů Hospodářské komory ČR a Agrární komory ČR, které jsou obě zř́zeny zákonem. ${ }^{87}$ Konečně posledním znakem je otázka př́tomnosti veřejnoprávního dohledu nad žalovaným. NSS v tomto bodě souhlasil se závěrem Městského soudu, že zde není veřejnoprávní dohled př́tomný vzhledem $\mathrm{k}$ požadavku na institucionální nezávislost žalovaného; to však dle NSS nevylučuje, aby byl žalovaný veřejnou institucí. ${ }^{88}$

NSS s odkazem na rozhodnutí Ústavního soudu připomněl, že při hodnocení, zda jde o veřejnou instituci, je třeba vyjít z převahy výše uvedených znaků a uzavřel, že žalovaný je povinným subjektem podle zákona č. 106/1999 Sb., o svobodném přístupu k informacím.

Autor: JM

\section{(DALŠÍ) ROZHODNUTÍ K OKRUHU POVINNÝCH SUBJEKTU゚ PODLE ZÁKONA Č. 106/1999 SB., O SVOBODNÉM PŘÍSTUPU K INFORMACÍM}

Soud: $\quad$ Ústavní soud

Věc: $\quad$ II. ÚS 618/18

Datum: 2. 4. 2019

Dostupnost: nalus.usoud.cz

Stěžovatel, sdružení Oživení, o. s., zaslal společnosti OTE, a. s. dne 22. 9. 2016 žádost podle zákona o svobodném prrístupu k informacím. Stěžovatel však vyřízení žádosti zamítl. ${ }^{89}$

\footnotetext{
86 Body 32-35 anotovaného rozhodnutí.

87 Bod 36 anotovaného rozhodnutí.

88 Bod 37 anotovaného rozhodnutí.

89 Bod 3 anotovaného nálezu.
} 
$\mathrm{V}$ reakci na to stěžovatel podal žalobu $\mathrm{k}$ Městskému soudu v Praze. ${ }^{90}$ Soud však žalobu odmítl s odkazem na argumentaci $\mathrm{v}$ nálezu ve věci ČEZ ${ }^{91}{ }^{92}$ Stěžovatel proto podal kasační stížnost, kterou Nejvyšší správní soud rozsudkem ${ }^{93}$ též zamítl. ${ }^{94}$ Stěžovatel se nakonec obrátil na Ústavní soud, přičemž namítal zejména porušení práva na přístup k informacím podle Listiny základních práv a svobod. ${ }^{95}$

Podstata sporu před Ústavním soudem spočívala v identifikaci, zdali může být společnost OTE, a. s., jakožto vedlejší účastník v tomto sporu, povinným subjektem podle zákona o svobodném přístupu $\mathrm{k}$ informacím. ${ }^{96}$ Konkrétně, zdali jakožto osoba soukromého práva může spadat pod pojem veřejné instituce, která je povinným subjektem podle $\S 2$ odst. 1 zákona o svobodném přístupu $\mathrm{k}$ informacím. ${ }^{97}$ Těžiště argumentace stěžovatele spočívalo v rozporu mezi výklady tohoto pojmu v nálezu ve věci ČEZ a nálezu ve věci Letiště Praha ${ }^{98}$. Ústavní soud souhlasil se stěžovatelem v tom, že předchozí judikatura je rozporuplná, a dospěl k názoru odchylujícímu se od názoru obsaženém v nálezu ve věci ČEZ. Ústavní soud se přiklonil k možnému podřazení obchodní společnosti pod pojem veřejné instituce, ${ }^{99}$ pokud je jejím stoprocentním vlastníkem stát, případně veřejnoprávní korporace. ${ }^{100}$ Ústavní soud rovněž zdůraznil nutnost vykládat zákon o svobodném přístupu k informacím podle svého smyslu, kterým je v maximální možné míre umožnit veřejnosti přístup $\mathrm{k}$ informacím. ${ }^{101}$

\footnotetext{
90 Bod 4 anotovaného nálezu.

91 Nález Ústavního soudu ze dne 20. 6. 2017, sp. zn. IV. ÚS 1146/16.

92 Srov. rozhodnutí Městského soudu v Praze ze dne 7. 9. 2017, č. j. 8 A 2015/216-48.

93 Rozsudek Nejvyššího správního soudu ze dne 12. 12. 2017, č. j. 7 As 311/2017-39

94 Bod 5 anotovaného nálezu.

95 Bod 6 anotovaného nálezu.

96 Bod 2 anotovaného nálezu.

97 Bod 14 a násl. anotovaného nálezu.

98 Nález Ústavního soudu ze dne 24. 1. 2017, sp. zn. I. ÚS 260/06.

99 Body 8-9 anotovaného nálezu.

100 Bod 16 anotovaného nálezu.

101 Bod 24 anotovaného nálezu.
} 
Ústavní soud proto ve výsledku shledal porušení práv garantovaných Listinou a zrušil předchozí soudní rozhodnutí ve věci. ${ }^{102}$

Celá část vlastního hodnocení Ústavního osudu je zajímavá jak z hlediska výkladu předchozích nálezů, tak i pro budoucí aplikaci § 2 odst. 1 zákona o svobodném př́stupu $\mathrm{k}$ informacím. ${ }^{103}$

Autorka: VŽ

\section{REGISTR SMLUV}

Soud: $\quad$ Ústavní soud

Věc: $\quad$ Pl. ÚS 32/17

Datum: $\quad 22.1 .2019$

Dostupnost: nalus.usoud.cz

Ústavní soud posuzoval návrh 30 senátorů na zrušení zákona o registru smluv. Pro účinnost takových smluv je dle $\S 5$ a násl. zákona stanoven požadavek nutného uveřejnění v registru smluv (čímž se rozumí vložení elektronického obrazu textového obsahu smlouvy $\mathrm{v}$ otevřeném a strojově čitelném formátu a rovněž příslušných metadat).

Senátoři v ústavní stižnosti požadovali zrušení celého zákona, alternativně pak požadovali alespoň omezení dopadu. Argumentaci opřeli zejména o to, že došlo $\mathrm{k}$ zásahu do principu autonomie vůle a principu rovnosti zakotveného v Listině základních práv a svobod. Zdůrazněn byl rovněž zásah do svobody podnikání; veřejnoprávní subjekty jsou tímto zákonem totiž nuceny zveřejňovat údaje, které by jinak mohly představovat konkurenční výhodu a $\mathrm{z}$ hlediska realizace práva na podnikání je jejich důvěrnost nezbytná.

Ústavní soud tak zkoumal cíl dané úpravy a konstatoval, že účelem zákona je zajištění transparentnosti prostřednictvím uveřejnění smluv, které se týkají nakládání $\mathrm{s}$ veřejnými financemi. ${ }^{104}$ Soud provedl $\mathrm{v}$ souvislosti s potenciálním porušením práva na podnikání test racionality a konsta-

\footnotetext{
102 Bod 25 anotovaného nálezu.

${ }^{103}$ Bod 14 a násl. anotovaného nálezu, zejm. body 19 a 20 .

${ }^{104}$ Bod 79 anotovaného rozhodnutí.
} 
toval, že v obecném měřítku $\mathrm{k}$ porušení základních práv nedošlo. ${ }^{105}$ Stejně tak soud zdůraznil, že uveřejnění smluv prostřednictvím registru nepředstavuje konkurenční výhodu jako takovou, protože zákon umožňuje omezit informace, které jsou v registru uveřejňovány. ${ }^{106}$ Výjimky jsou stanoveny například pro obchodní tajemství, smlouvy související s finančními trhy či doplňkovou činností veřejných vzdělávacích institucí, což umožňuje reflektovat specifické situace. ${ }^{107}$ Soud rovněž zdůraznil, že subjekty nakládají s veřejnými prostředky, „což legitimně odůvodňuje potrebu dbát na jejich hospodárné využívání." ${ }^{108}$ Pokud je pak subjekt napojen na veřejné finance, nelze akceptovat, že by byl ve srovnatelném postavení, $\mathrm{v}$ jakém by byly mezi sebou ryze soukromoprávní subjekty. ${ }^{109}$

Ústavní soud tak stížnost zamítl a zdůraznil, že se jednalo o zkoumání abstraktní (ve smyslu účelu a dopadu právní úpravy jako celku), nikoli posuzování individuální situace.

Nález tak potvrdil názor, že veřejný sektor je v porovnání se soukromým sektorem v méně výhodném postavení, co se svobody podnikání, dané však opřel o argument nakládání s veřejnými financemi. Problém do budoucna nicméně shledáváme v interpretací některých výjimek, které jsou sami o sobě poměrně vágně vymezeny.

Autor: PL

\footnotetext{
${ }^{105}$ Bod 78 anotovaného rozhodnutí.

${ }^{106}$ Bod 76 anotovaného rozhodnutí.

107 § 3 odst. 2 zákona o registru smluv.

108 Bod 78 anotovaného rozhodnutí.

${ }^{109}$ Bod 87 anotovaného rozhodnutí.
} 


\section{BALENÍ SCHWARZWÄLDER SCHINKEN V OBLASTI PRODUKCE}

Soud:

Věc:

Datum:

Dostupnost:
Soudní dvůr Evropské unie

$$
\text { C-367/17 (S) }
$$

19. 12. 2018

$$
\text { curia.europa.eu }
$$

Spolek S požádal německý patentový a známkový úřad (DPMA) o změny specifikace chráněného zeměpisného označení „Schwarzwälder Schinken“, a to v rozsahu týkajícího se údajů o krájení a balení. Proti této žádosti však podala námitky společnost EC, jež jako distributor masných výrobků provádí krájení a balení výrobku s daným chráněným zeměpisným označením mimo oblast produkce.

DPMA žádost o změnu specifikace zamítl, načež spolek $S$ podal proti tomuto rozhodnutí stížnost s návrhem na změnu rozhodnutí. Spolkový patentový soud rozhodnutí DPMA zrušil a rozhodl, že žádost o změnu specifikace byla v souladu s požadavky nařízení č. 510/2006. EC proto podala kasační opravný prostř̌edek. V mezičase však bylo dosavadní nařízení č. 510/2006 nahrazeno nařízením č. 1151/2012. Spolkový soudní dvůr rozhodnutí zrušil a vrátil ho zpět, na což Spolkový patentový soud reagoval položením předběžných otázek.

Soudní dvůr byl tázán, zda má být rozhodnutí o žádosti o změnu specifikace chráněného zeměpisného označení přijato na základě nařízení č. 510/2006 platného $\mathrm{k}$ datu podání žádosti, nebo na základě nařízení č. 1151/2012 platného $\mathrm{k}$ datu přijetí rozhodnutí. Další otázky směřovaly na odůvodněnost požadavku balení „Schwarzwälder Schinken“ v oblasti produkce, pokud je účelem takového požadavku vyloučit riziko nežádoucích účinků na jakost výrobku, které hrozí v případě balení mimo oblast produkce.

Soudní dvưr k první otázce uvedl, že předmětná ustanovení obou nařízení jsou v podstatě totožná, a proto není potřeba na první otázku odpoví- 
dat. ${ }^{110} \mathrm{~K}$ dalším otázkám uvedl, že se $\mathrm{v}$ rámci společné zemědělské politiky projevuje tendence stavět do popředí jakost produktů s cílem podpořit dobrou pověst takovýchto produktů a též uspokojit očekávání spotřebitelů. ${ }^{111}$ Podmínka krájení a balení v oblasti produkce má umožnit uživatelům konkrétního chráněného zeměpisného označení zachování dohledu nad prezentací produktu na trhu. ${ }^{112}$ Soudní dvůr zdůraznil, že projednávaný požadavek je relevantní pouze $\mathrm{v}$ př́ípadě, že balení mimo zeměpisnou oblast produkce uvedeného produktu vyvolává zvýšená rizika pro jakost tohoto produktu, nikoli jsou-li totožným rizikům vystaveny jiné podobné produkty. ${ }^{113}$

Soudní dvưr konstatoval, že požadavek týkající se balení produktu v zeměpisné oblasti jeho produkce je odůvodněný, pokud je nezbytným a přiměřeným nástrojem pro zachování jakosti produktu, zaručení jeho původu a zajištění kontroly specifikace chráněného zeměpisného označení. ${ }^{114}$ Vnitrostátní soud je pak podle Soudního dvora povinen posoudit, zda je tento požadavek v konkrétní věci „Schwarzwälder Schinken“ řádně odůvodněn jedním z výše uvedených cílů. ${ }^{115}$

Autorka: IK

\footnotetext{
${ }^{110}$ Bod 19 anotovaného rozhodnutí.

111 Bod 24 anotovaného rozhodnutí.

${ }^{112}$ Bod 25 anotovaného rozhodnutí.

${ }^{113}$ Bod 28 anotovaného rozhodnutí.

114 Bod 36 anotovaného rozhodnutí.

115 Tamtéž.
} 


\title{
KOLEKTIVNÍ SPRÁVA PŘI POUHÉM UMÍSTĚNÍ TELEVIZORU A
}

\section{RÁDIA V RESTAURACI}

Soud:

\author{
Ústavní soud
}

Věc:

III. ÚS 3102/16

Datum:

21. 5. 2019

Dostupnost: nalus.usoud.cz

Stěžovatel provozuje restauraci, ve které byla na konci roku 2013 provedena kontrola kolektivním správcem INTERGRAM, nezávislá společnost výkonných umělců a výrobců zvukových a zvukově-obrazových záznamů, z. s. Touto kontrolou bylo zjištěno, že se v restauraci nachází televizor a rádio, kterými mělo být zákazníkům zpřístupňováno televizní a rozhlasové vysílání, aniž by přitom stěžovatel uzavřel př́islušnou smlouvu s kolektivním správcem.

INTERGRAM proto podal proti stěžovateli žalobu na vydání bezdůvodného obohacení v hodnotě bezmála 10.000,- Kč s úrokem z prodlení. V návaznosti na to a po pofidérním dokazování Krajský soud v Praze rozhodl ve prospěch kolektivního správce. ${ }^{116}$ Stěžovatel se proto obrátil na Ústavní soud pro nerespektování judikatury Ústavního soudu ve věci prokazování porušení autorského práva a sdělování veřejnosti, judikatury Nejvyššího soudu ohledně autorských odměn, jakož i porušení svého práva na spravedlivý proces ve smyslu čl. 36 Listiny základních práv a svobod daným krajským soudem.

Po kladném posouzení splnění procesních předpokladů řízení Ústavní soud odkázal na svou předchozí judikaturu a vymezení obecných náležitostí kontroly kolektivním správcem, který tak podle Ústavního soudu musí provést tzv. třístupňový test (sic!), ${ }^{117}$ tj. zkoumat (i) existenci sdělování veřejnosti, (ii) skutečný výkon kolektivní správy a (iii) existenci smlouvy

\footnotetext{
${ }^{116}$ Stalo se tak rozsudkem Krajského soudu v Praze ze dne 28. 6. 2016, č. j. 139 EC 53/2014180.

${ }^{117}$ Bod 17 anotovaného rozhodnutí.
} 
provozovatele s daným kolektivním správcem. ${ }^{118}$ Ústavní soud též podal základní výklad pojmu „výkonný umělec“ ve smyslu § 67 zákona č. 121/2000 Sb., autorského zákona, pro potřeby daného př́ipadu. ${ }^{119} \mathrm{~V}$ neposlední řadě Ústavní soud apeloval na Krajský soud v Praze v otázce nutnosti prokazování zásahu do autorských práv kolektivním správcem zastupovaných osob. ${ }^{120}$

Ústavní soud proto (bez nařízení ústního jednání) uzavřel, že závěry krajského soudu byly nedostatečné pro nemožnost jednoznačného závěru sdělování veřejnosti a výkonu kolektivní správy na základě provedených důkazů, čímž bylo zasaženo do práva stěžovatele na spravedlivý proces. Rozhodnutí krajského soudu bylo proto zrušeno.

Ústavní soud tímto rozhodnutím napomáhá budovat na jedné straně doktrínu sdělování veřejnosti a jeho presumpce, na straně druhé vyjasňuje pozici kolektivního správce. Ze závěru soudu plyne, že z pouhé existence provozuschopného televizoru a rádia $\mathrm{v}$ restauraci ještě nelze bez dalšího dovozovat nutnost uzavření smlouvy s kolektivním správcem, resp. nelze dovozovat, že dochází $\mathrm{k}$ bezdůvodnému obohacení.

Autor: JZ

\section{SKLADOVÁNÍ ZBOŽÍ JAKO ROZŠIŘOVÁNÍ DÍLA}

Soud: $\quad$ Soudní dvůr Evropské unie

Věc: $\quad$ C-572/17 (Syed)

Datum: $\quad$ 19. 12. 2018

Dostupnost: curia.europa.eu

Pan Syed prodával ve svém obchodě výrobky s chráněnými motivy, přičemž zboží skladoval nedaleko. Při prodeji mělo být zasahováno do výlučných práv plynoucích z autorskoprávní ochrany a ochranných známek k motivům. Státní zástupce proto zahájil trestní stíhání pro porušování au-

\footnotetext{
118 Body 10 a násl. anotovaného rozhodnutí.

${ }^{119}$ Bod 15 anotovaného rozhodnutí.

${ }^{120}$ Bod 16 anotovaného rozhodnutí.
} 
torského práva a práv $\mathrm{k}$ ochranným známkám protiprávním zpřístupňováním motivi̊ veřejnosti.

Soud prvního stupně odsoudil pana Syeda za porušení práv k ochranným známkám v souvislosti s veškerým odhaleným zbožím a za zásah do autorského práva $\mathrm{v}$ souvislosti se zbožím opatřeným chráněným motivem, které se nacházelo v obchodě, jakož i se zbožím, které se nacházelo ve skladech a bylo totožné $s$ prodávaným zbožím. Odvolací soud zmírnil trest a uvedl, že dané porušení práv nelze vztahovat ke skladovanému zboží. Nejvyšší soud pro nejasný výklad čl. 4 směrnice 2001/29 vznesl předběžnou otázku.

Soudní dvưr byl tázán, zda může docházet k porušení výlučného práva autora na rozšiřování díla (čl. 4 směrnice) i ve vztahu ke zboží s týmiž motivy, jež je skladováno ve skladech stejnou osobou, která nabízí zboží k prodeji. Druhá otázka se týkala relevance polohy skladu.

Soudní dvůr apeloval na mezinárodně konformní výklad. ${ }^{121}$ Zdůraznil, že $\mathrm{k}$ porušení výlučného práva na rozšiřování může dojít i jen nabídkou k uzavření kupní smlouvy; ${ }^{122}$ uskutečnění prodeje tak není nezbytným prvkem, ačkoliv musí být prokázáno, že zboží je určeno k rozšiřování. ${ }^{123}$ Soudní dvůr pak klasifikoval skladování zboží s chráněnými motivy jako úkon předcházející uskutečnění prodeje, jenž může představovat porušení výlučného práva na rozšiřování. ${ }^{124}$ Př́slušný soud přitom musí posoudit, zda bylo veškeré zboží, které je totožné se zbožím prodávaným v obchodě, nebo pouze část zboží, určeno k uvádění na trh v této prodejně. ${ }^{125}$

Soudní dvůr konstatoval, že skladování zboží (které je opatřeno motivem chráněným autorským právem na území členského státu) obchodníkem může představovat porušení výlučného práva na rozšiřování, pokud daný obchodník nabízí bez svolení nositele autorského práva v obchodě k prodeji zboží, které je totožné se zbožím, jež skladuje; a to za pod-

\footnotetext{
${ }^{121}$ Body 19 a 20 anotovaného rozhodnutí.

${ }^{122}$ Body 24 až 26 anotovaného rozhodnutí.

${ }^{123}$ Bod 27 anotovaného rozhodnutí.

${ }^{124}$ Bod 31 anotovaného rozhodnutí.

${ }^{125}$ Bod 36 anotovaného rozhodnutí.
} 
mínky, že skladované zboží je určeno k prodeji na území členského státu, kde je motiv chráněn. Vzdálenost mezi místem skladování a místem prodeje nemůže být navíc rozhodujícím prvkem pro určení, zda je skladované zboží určeno $\mathrm{k}$ prodeji.

Rozhodnutí rozšiřuje výkladovou doktrínu ke směrnici 2001/29 a je další vlaštovkou svědčící o extenzivním výkladu jednotlivých práv.

Autor: JZ

\section{MŮŽE DVOJROZMĚRNÝ VÝROBEK OBSAHOVAT OZNAČENÍ TVOŘENÉ VÝLUČNĚ TVAREM?}

Soud: $\quad$ Soudní dvůr Evropské unie

Věc: $\quad$ C-21/18 (Textilis)

Datum: $\quad$ 14. 3. 2019

Dostupnost: curia.europa.eu

Švédská společnost Svenskt Tenn obchodovala s textiliemi obsahujícími motiv MANHATTAN chráněný ochrannou známkou EU. ${ }^{126}$ Britská společnost Textilis začala v roce 2013 používat vzor podobný tomuto motivu, v čemž švédská společnost spatřovala zásah do práv k ochranné známce a dožadovala se zákazu užívání ochranné známky.

Švédský soud prvního stupně rozhodoval o žalobě společnosti Svenskt Tenn pro porušení práv k ochranné známce MANHATTAN. Navíc paralelně posuzoval i žalobu společnosti Textilis, aby byla ochranná známka MANHATTAN prohlášena za neplatnou pro absenci rozlišovací způsobilosti a tvoření pouhým tvarem (absolutní důvody zápisné nezpůsobilosti). Soud žalobu britské společnosti zamítl a švédské společnosti přitakal rozhodnutím o zásahu do práv z ochranné známky. Odvolací soud se pak zamýšlel nad aplikací důvodu, kdy je označení tvořeno pouhým tvarem, v případě dvojrozměrného výrobku; pro nejasnosti však vznesl předběžné otázky.

První otázka se týkala intertemporálních ustanovení nařízení 2015/2424, které pozměňovalo nařízení č. 207/2009 o ochranné známce

\footnotetext{
${ }^{126}$ Pro vyobrazení motivu srov. bod 12 anotovaného rozhodnutí.
} 
Společenství, a to v situaci, kdy byla žaloba podána před platností takového nařízení a ohledně dříve zapsané ochranné známky. Další dvě otázky cílily na aplikaci absolutního důvodu zápisné nezpůsobilosti, kdy je označení tvořeno výlučně tvarem, na dvojrozměrné výrobky a kritéria pro posuzování aplikace daného důvodu.

Soudní dvůr k první otázce uvedl s odkazem na předchozí judikaturu, že je třeba posuzovat smysl nařízení a jeho vztah $\mathrm{k}$ dané situaci. ${ }^{127} \mathrm{Na}$ adresu druhé otázky poznamenal, že definice "tvaru“ neexistuje. ${ }^{128} \mathrm{~S}$ odkazem na judikaturu uvedl, že ač v dané věci označení vykazuje tvary, které jsou tvořeny vnějšími obrysy vyobrazení, označení spočívající v dvojrozměrných dekorativních vzorech nesplývá s tvarem výrobku, je-li umístěno na takových výrobcích, jako je textil či tkanina. ${ }^{129}$

Soudní dvưr rozhodl, že pozměněné nařízení č. 207/2009 se nepoužije na ochranné známky zapsané před vstupem pozměňovacího nařízení v platnost. K aplikaci důvodu absolutní zápisné nezpůsobilosti pak uvedl, že označení spočívající ve dvojrozměrných vzorech umístěných na výrobcích, jako je textil či tkanina, není „tvořeno výlučně tvarem“ ve smyslu čl. 7 nařízení.

Rozhodnutí je zajímavé jednak s ohledem na řešení intertemporálních otázek dříve platného nařízení, kterážto otázka může být obdobně zajímavá i s nařízením č. 2017/1001, jednak s ohledem na ujasnění doktrinální pře ohledně aplikace daného důvodu na dvojrozměrný výrobek.

Autor: JZ

\footnotetext{
${ }^{127}$ Body 29 a násl. anotovaného rozhodnutí.

${ }^{128}$ Bod 35 anotovaného rozhodnutí.

${ }^{129}$ Body 37 až 42 anotovaného rozhodnutí.
} 


\title{
DILIA PROTI ULOZ.TO
}

\author{
Soud: $\quad$ Městský soud v Praze \\ Věc: $\quad 34$ C $5 / 2017-360$ \\ Datum: 22. 2. 2019 \\ Dostupnost: získáno na základě zákona č. 106/1999 Sb., o svobodném \\ přístupu k informacím
}

Žalovaná společnost Uloz.to cloud a.s. provozuje nejnavštěvovanější českou datovou úschovnu Uloz.to, na které byla sdílena mj. autorská díla Obušku, z pytle ven!, Ostře sledované vlaky, S čerty nejsou žerty, Vesničko má středisková, Pelíšky a Kobry a užovky. Žalobce, spolek DILIA, divadelní, literární, audiovizuální agentura, z.s., coby kolektivní správce majetkových práv autorských $\mathrm{k}$ daným dílům ( $\mathrm{v}$ rozsahu práva na sdělování veřejnosti) na žalovanou apeloval, aby se jednání zdržela. Po neúspěšné snaze se pak obrátil na soud s nárokem vyplývajícím z práva duševního vlastnictví, jelikož žalovaná dle jeho slov poskytovala protiprávní službu, která slouží ke sdílení zákonem chráněných děl.

Soud po rekapitulaci žalobcových tvrzení o fungování úložiště uvedl, že žalovaná nenese odpovědnost za obsah souborů ukládaných na úložiště, ${ }^{130}$ a že principy, na základě kterých je služba úložiště poskytována, nepovažuje za protiprávní. ${ }^{131}$ Zdůraznil navíc, že žalovaná činí určité kroky směřující mj. k ochraně autorských práv ve smyslu § 5 zákona č. 480/2004 Sb., o některých službách informační společnosti, a celkově je počínání v souladu s principem odpovědnosti poskytovatele takové služby. S odkazem na důvodovou zprávu k tomuto zákonu pak ale shledal ochranu autorských práv ze strany žalované za nedostatečnou, zejména $\mathrm{v}$ situaci, kdy předmětem řízení je jen šestice filmů, nikoliv obecný apel na celkovou filtraci úložiště, kterážto by byla nepřiměřená. ${ }^{132}$ Soud se navíc $\mathrm{v}$ krátkosti vyjádřil též

\footnotetext{
${ }^{130}$ Bod 25 anotovaného rozhodnutí.

${ }^{131}$ Bod 26 anotovaného rozhodnutí.

${ }^{132}$ Bod 27 anotovaného rozhodnutí.
} 
k širšímu kontextu provozování úložiště a případnému střetu se svobodným přístupem $\mathrm{k}$ informacím. ${ }^{133}$

Soud nakonec zamítl návrh žalobce na odstranění či znepřístupnění veřejnosti digitálních souborů obsahujících uvedená audiovizuální díla a zdržení se do budoucna jejich zpřístupňování veřejnosti. Dalším výrokem však rozhodl, že žalovaná je povinna zdržet se umožnění veřejného zpřístupňování digitálních souborů specifikovaných přípon obsahující uvedená audiovizuální díla, pokud můžou členové veřejnosti tyto soubory vyhledat zadáním titulu díla (s diakritikou či bez ní) ve vyhledávači poskytnutém $\mathrm{k}$ tomu veřejnosti žalovaným.

Jedná se o první rozhodnutí ve věci nelegálního sdělování audiovizuálních děl veřejnosti pomocí úložiště Uloz.to, které vedlo k částečnému znepřístupnění problematických děl. Soudní rozhodnutí navíc přehledně popisuje odpovědnost ISP v tomto kontextu a nebojí se kriticky zamýšlet nad širšími souvislostmi.

Autor: JZ

\section{NEOPRÁVNĚNÉ ZPŘÍSTUPNĚNÍ TELEVIZNÍHO VYSÍLÁNÍ FORMOU ODKAZU}

Soud: $\quad$ Nejvyšší soud

Věc: $\quad 5$ Tdo $692 / 2018$

Datum: $\quad$ 15. 8. 2018

Dostupnost: nsoud.cz

Dovolatel umožňoval sledování televizního vysílání prostřednictvím webových stránek, na které umístil odkazy umožňující přístup na jiné webové stránky s vysíláním televizních stanic. Obsah televizního vysílání byl na tomto místě přitom umístěn protiprávně. I přesto, že licenční práva držely jiné subjekty, umožnil dovolatel dalším jemu neznámým osobám k danému vyslání přístup. ${ }^{134}$ Činil tak přitom vědomě a delší dobu bez sou-

\footnotetext{
${ }^{133}$ Body 32 a násl. anotovaného rozhodnutí.

${ }^{134}$ Bod 3 anotovaného rozhodnutí.
} 
hlasu vlastníka či držitele licence vysílacích práv. Ani sám dovolatel pak předmětnou licenci nevlastnil. ${ }^{135}$

Dovolatel byl proto za své jednání soudy nižších stupňů shledán vinným přečinem porušení autorského práva, práv souvisejících s právem autorským a práv k databázi podle $\S 270$ odst. 1 zákona č. 40/2009 Sb., trestního zákoníku. ${ }^{136}$ Dle dovolatele došlo $\mathrm{k}$ nesprávnému hmotněprávnímu posouzení daného skutku. ${ }^{137}$ Dovolatel měl za to, že pouhé odkazování na jiné internetové stránky není trestné. ${ }^{138}$

Nejvyšší soud se v rámci dovolacího řízení vyjádřil k tomu, zda dovolatel svým výše uvedeným jednáním zasáhl nikoli nepatrně do práv k televiznímu vysílání chráněných autorským zákonem. Rozhodnutí shrnuje, že v daném trestním řízení nebylo pochyb o tom, že by byl zásah do vysílacích práv ze strany dovolatele nepatrný, a to s odkazem na dobu pokračování v zásahu převyšující jeden rok; na množství stránek, jejichž prostřednictvím vysílaní veřejnosti sděloval, a na to, že tak činil za účelem dosažení zisku. ${ }^{139}$ Soud při posuzování kritéria dosažení zisku připomněl judikaturu Soudního dvora Evropské unie. ${ }^{140,141}$ Byl-li totiž odkaz na protiprávně zveřejněné dílo umístěn za účelem dosažení zisku, lze očekávat, že původce odkazu provede nezbytná ověření, aby zjistil, zda dotčené dílo není zveřejněno protiprávně. Odkáže-li pak osoba na nelegálně zveřejněné dílo, lze se domnívat, že je se zásahem do práv $k$ dílu při nejmenším srozuměna. ${ }^{142}$ Jednání dovolatele bylo dle soudu motivováno dosažením zisku, nebot dovolatel uvažoval o tom, že by vysílání zpoplatnil, a navíc měl mít i příjem z reklam. Nadto byl dodavatel na protiprávnost svého jednání upozorněn jedním z držitelů vysílacích práv.

\footnotetext{
${ }^{135}$ Bod 22 anotovaného rozhodnutí.

${ }^{136}$ Bod 1 a 2 anotovaného rozhodnutí.

${ }^{137}$ Bod 4 anotovaného rozhodnutí.

138 Bod 5 anotovaného rozhodnutí.

139 Bod 26 anotovaného rozhodnutí.

140 Zejména rozsudek SDEU ve věci C-160/15 ze dne 8. září 2016, GS Media.

${ }^{141}$ Bod 31 anotovaného rozhodnutí.

${ }^{142}$ Bod 31 a násl. anotovaného rozhodnutí.
} 
Nejvyšší soud tedy uzavřel, že dovolatel neměl pochyb o tom, že jednal protiprávně a že neoprávněně zasahoval do zákonem chráněných práv $\mathrm{k}$ televiznímu vysílání. Nejen, že tak byl s porušením zákonem chráněných práv k televiznímu vysílání srozuměn, ale tato práva porušovat i chtěl. ${ }^{143}$ Dovolání proto bylo soudem odmítnuto pro svou zjevnou neopodstatněnost. ${ }^{144}$

Toto rozhodnutí se řadí mezi ta, která ukazují, že i odkazem může být za určitých okolností spáchán trestný čin.

Autor: JS

\section{ODPOVĚDNOST ZPRAVODAJSKÉHO PORTÁLU ZA OBSAH ODKAZOVANÝ POMOCÍ HYPERLINKU Z PERSPEKTIVY PRÁVA NA SVOBODU PROJEVU}

Soud: $\quad$ Evropský soud pro lidská práva

Věc: $\quad 11257 / 16$

Datum: $\quad$ 4. 12.2018

Dostupnost: hudoc.echr.coe.int

Navrhovatel, společnost Magyar Jeti Zrt., provozuje zpravodajský internetový portál 444.hu, který zveřejnil hyperlinkový odkaz na audiovizuální obsah na platformě Youtube. Obsah tohoto videa byl později soudem označen jako pomlouvačný. ${ }^{145}$

Navrhovatel byl jedním z několika žalovaných, proti kterým mad’arská politická strana Jobbik podala žalobu pro pomluvu, které se měli dopustit odkazem na zmíněné video, ve kterém byla strana označena za pachatele rasisticky motivovaných výtržností. ${ }^{146}$ Mad’arský soud svým rozsudkem žalobě vyhověl. ${ }^{147}$ Navrhovatel se odvolal, nicméně odvolací soud rozhodnutí potvrdil. ${ }^{148} \mathrm{U}$ Ústavního soudu pak navrhovatel argumentoval tím,

\footnotetext{
${ }^{143}$ Bod 33 anotovaného rozhodnutí.

${ }^{144}$ Bod 34 anotovaného rozhodnutí.

145 Bod 3 anotovaného rozhodnutí.

${ }^{146}$ Body 6-12 anotovaného rozhodnutí.

147 Bod 13 anotovaného rozhodnutí.

${ }^{148}$ Bod 16 anotovaného rozhodnutí.
} 
že národní judikaturní praxe činí jakéhokoliv zpravodaje odpovědného za pravdivost prohlášení třetích stran, čímž omezuje svobodu projevu. ${ }^{149}$ Ústavní soud stížnost zamítnul s tím, že odkaz představuje šîrení informací, které může být nezákonné $\mathrm{i} v$ př́ípadě, kdy se šiřitel zjevně neidentifikuje s odkazovaným obsahem, a to $s$ odkazem na místní právní úpravu a princip objektivní odpovědnosti. ${ }^{150}$

ESLP se zaobíral otázkou, zdali objektivní odpovědnost podle mad’arského práva nepředstavuje porušení čl. 10 Úmluvy. Hlavními argumenty pro rozhodnutí soudu bylo zaprvé, že z mad’arského práva nebylo zjevné, že hyperlink může být způsobem šiřrení nezákonných informací, a kvůli neexistující judikatuře nemohl zpravodaj tuto klasifikaci předvídat. ${ }^{151}$ Zadruhé, že hyperlink je potřeba vnímat jako novou formu zpravodajství, přičemž ten, kdo jej umístí, nutně nevyjadřuje žádný konkrétní sentiment k odkazovanému obsahu. ${ }^{152}$ Proto není žádoucí tuto formu a priori omezit. ${ }^{153}$ Soud proto identifikoval podpůrná kritéria, která by musela být splněna, aby byl zpravodaj odpovědný za odkazovaný nezákonný obsah: (i) vyjádření podpory k obsahu, (ii) opakování obsahu, (iii) znalost, že je obsah pomluvou nebo jinak nezákonný. ${ }^{154}$

ESLP dospěl k závěru, že objektivní odpovědnost podle mad’arského práva není v souladu s těmito kritérii a působí negativně na využívání základního lidského práva na svobodu projevu a př́stup $\mathrm{k}$ informacím. ${ }^{155}$ Soud proto shledal porušení Úmluvy. ${ }^{156}$

Rozhodnutí je zajímavé z hlediska důkladné analýzy mezinárodní i národní judikatury zabývající se povahou hyperlinku ${ }^{157}$, která byla zatím řeše-

\footnotetext{
149 Bod 17 anotovaného rozhodnutí.

150 Body 20 a 25 anotovaného rozhodnutí.

${ }^{151}$ Bod 60 anotovaného rozhodnutí.

${ }^{152}$ Body 73 - 75 anotovaného rozhodnutí.

153 Bod 73 anotovaného rozhodnutí.

154 Bod 77 anotovaného rozhodnutí.

155 Bod 83 anotovaného rozhodnutí.

${ }^{156}$ Bod 93 anotovaného rozhodnutí.

157 Bod 77 anotovaného rozhodnutí.
} 
na zejména $\mathrm{z}$ pohledu autorského práva. ${ }^{158}$ Stejně tak je případ zajímavý pro svůj přesah do práva na svobodu projevu, kterážto argumentační linie se kupříkladu v rozhodovací praxi Soudního dvora Evropské unie nevyskytuje.

Autorka: VŽ

\section{PŘÍPUSTNOST ELEKTRONICKÝCH DŮKAZU゚ ZÍSKANÝCH ZA POMOCI PODPŮRNÝCH OPERATIVNĚ PÁTRACÍCH PROSTŘEDKU゚}

Soud: $\quad$ Ústavní soud

Věc:

III. ÚS 3564/18

Datum: $\quad$ 28. 5. 2019

Dostupnost: nalus.usoud.cz

Spor se týkal jednání Policie ČR v roce 2014, která zabránila stěžovatelce formou výzvy dle § 43 odst. 1 písm. a) zákona č. 273/2008 Sb., o Policii ČR, ${ }^{159} \mathrm{v}$ účasti na protestu proti průvodu Prague Pride v rámci opatření pro zamezení násilí. ${ }^{160}$ Při posuzování věci obvodním soudem byly mimo jiné předloženy jako důkazy tři printscreeny ${ }^{161}$ neveřejných příspěvků osoby organizující protest proti pochodu ze sociální sítě Facebook, které byly získány pomocí podpůrných operativně pátracích prostř̌edků. ${ }^{162}$

U obvodního soudu v Praze stěžovatelka namítala nesprávný úřední postup, soud však žalobu zamítl. ${ }^{163}$ Výroky soudu následně potvrdil i odvolací Městský soud v Praze. ${ }^{164}$ Stěžovatelka tedy podala ústavní stížnost.

Zde namítala zásah do ústavně zaručeného práva na svobodu projevu dle čl. 17 odst. 1 LZPS a nepřípustným procesem dokazování též do práv na

\footnotetext{
${ }^{158}$ Body 26-32 anotovaného rozhodnutí.

${ }^{159}$ Blíže viz body 3 a 34 anotovaného nálezu.

160 Bod 2 anotovaného nálezu.

161 Jedná se o zachycení obsahu obrazovky do obrazového souboru.

${ }^{162}$ Bod 14 anotovaného nálezu. Blíže viz § 72 zákona č. 273/2008 Sb., o Policii ČR.

${ }^{163}$ Bod 3 anotovaného nálezu.

${ }^{164}$ Bod 4 anotovaného nálezu.
} 
nezávislý soud a rovnost účastníků řízení před soudem dle čl. 36 odst. 1 a 37 odst. 3 LZPS. $^{165}$

K nepřípustnosti důkazu printscreeny získaných operativní činností policie $^{166}$ stěžovatelka odkazovala na předchozí závěry soudu. ${ }^{167}$ Ústavní soud však upřesnil, že se v dané věci nijak nezabýval přípustností získání těchto důkazů podpůrnými operativními pátracími prostředky. ${ }^{168}$ Dále zdůraznil, že úprava $§ 72$ zákona o Policii ČR umožňuje získání printscreenů od informátora bez příkazu či souhlasu soudu. ${ }^{169}$ Stejně tak není zapotřebí souhlasu soudu pro operování za pomoci zastřených profilů policistů na sociálních sítích. ${ }^{170}$ Takto získané informace je následně možné využít i k předcházení trestným činům, ochraně veřejného pořádku či vedení správního řízení před policií jako správním orgánem. ${ }^{171}$ Ústavní soud tedy v tomto směru nepřisvědčil námitce stěžovatelky. Stěžovatelce však přisvědčil, že výzva policie zamezující jí vstup do prostoru průvodu není ústavně zdůvodnitelná, pokud nebylo prokázáno, že stěžovatelka hodlala účastníkům pochodu vyhrožovat násilím. ${ }^{172}$ Jen pravděpodobnost vzniku napětí nepostačuje pro znemožnění vyjádření nesouhlasu v blízkosti průvodu. ${ }^{173}$

Ústavní soud konstatoval porušení stěžovatelčina práva na svobodu projevu, a proto rozsudek městského soudu zrušil.

Autor: FK

\footnotetext{
${ }^{165}$ Bod 1 anotovaného nálezu.

${ }^{166}$ Bod 15 anotovaného nálezu.

${ }^{167}$ Bod 16 anotovaného nálezu. Stěžovatelka ve své argumentaci odkazovala na nález Ústavního soudu ze dne 30. 10. 2014, sp. zn. III. ÚS 3844/13.

168 Bod 18 anotovaného nálezu.

169 Bod 22 anotovaného nálezu.

${ }^{170}$ Bod 23 anotovaného nálezu.

${ }^{171}$ Bod 24 anotovaného nálezu.

${ }^{172}$ Bod 53 anotovaného nálezu.

${ }^{173}$ Bod 54 anotovaného nálezu.
} 


\section{ŽIVÉ STREAMOVÁNÍ JAKO PROVOZOVÁNÍ SÍTĚ ELEKTRONICKÝCH KOMUNIKACÍ PRO ŠÍŘENÍ ROZHLASOVÉHO NEBO TELEVIZNÍHO VYSÍLÁNí}

Soud: $\quad$ Soudní dvůr Evropské unie

Věc: $\quad$ C-298/17 (France Télévisions)

Datum: $\quad$ 13. 12.2018

Dostupnost: curia.europa.eu

Společnost Playmédia nabízela sledování televizních programů prostřednictvím živého streamování po internetu a svoji činnost financovala hlavně z vysílání reklamních sdělení, které předchází a doprovází uvedené sledování. Protože se společnost Playmédia považovala dle francouzského práva za poskytovatele služeb, nárokovala si právo šířit programy vysílané společností France Télévisions. Společnost France Télévisions však sama šířila uvedené programy prostřednictvím živého streamování po internetu.

Nejvyšší rada pro audiovizuální vysílání vyzvala France Télévisions, aby nebránila společnosti Playmédia přebírat programy jí vysílané pro účely streamování. France Télévisions podala proti této výzvě žalobu v kanceláři Conseil d'État, která se rozhodla přerušit řízení a položit Soudnímu dvoru předběžné otázky.

Předběžné otázky předložené Soudnímu dvoru se týkaly výkladu čl. 31 směrnice 2002/22/ES o univerzální službě a právech uživatelů týkajících se sítí a služeb elektronických komunikací a směrnice 2002/21/ES o společném předpisovém rámci pro sítě a služby elektronických komunikací. Zejména se Soudní dvůr zabýval otázkami, zda podnik, který nabízí sledování televizních programů prostřednictvím živého streamování, má být považován za podnik, který poskytuje sít elektronických komunikací používanou pro veřejné šíření rozhlasového a televizního vysílání a dále jednotlivými podmínkami povinnosti šíření (must carry) dle evropského práva.

V projednávané věci Soudní dvůr uvedl, že společnost Playmédia, která se omezuje na nabízení sledování televizních programů prostřednictvím 
živého streamování po internetu, nezajištuje sít elektronické komunikace, ale naopak nabízí přístup $\mathrm{k}$ obsahu audiovizuálních služeb poskytovaných na sítích elektronických komunikací. ${ }^{174}$ Soudní dvůr v rozhodnutí uvedl, že činnost spočívající v nabízení sledování televizních programů prostřednictvím živého streamování po internetu nespadá do definice podniku, který poskytuje sít elektronických komunikací používanou pro veřejné šíření rozhlasového a televizního vysílání. ${ }^{175}$ Pouhá skutečnost, že podnik pro účely nabízení uvedených služeb využívá sít elektronických komunikací, jak ji definuje čl. 2 písm. a) směrnice 2002/21/ES, tedy internet, totiž neumožňuje považovat jej za poskytovatele sítě elektronických komunikací. Dále Soudní dvůr konstatoval, že ustanovení směrnice 2002/22/ES musí být vykládána tak, že nebrání tomu, aby členský stát uložil povinnost šíření podnikům, které nabízejí sledování televizních programů prostřednictvím živého streamování po internetu, aniž zajištují sítě elektronické komunikace. Členský stát tedy může rozšíriit povinnost šiřrení i na okruh subjektů stojících mimo působnost stanovenou v čl. 31 směrnice 2002/22/ES. ${ }^{176}$

Soudní dvưr v dané věci uzavřel, že provozování živého vysílání není poskytováním elektronických komunikací. Zároveň Soudní dvůr stanovil, že členské státy mají možnost uložit povinnost šiřrení i nad rámec povinných subjektů dle evropského práva.

Autorka: DG

\section{DALŠÍ VÝVOJ V KAUZE UBER}

Soud: Ústavní soud

Věc: $\quad$ III. ÚS 4072/17

Datum: 5. $\quad$ 51. 2018

Dostupnost: nalus.usoud.cz

Žalovaná společnost Uber provozovala $\mathrm{v}$ Brně své služby spočívající ve zprostředkování kontaktu mezi řidičem a pasažérem prostř̌ednictvím mobi-

\footnotetext{
${ }^{174}$ Bod 19 anotovaného rozhodnutí.

${ }^{175}$ Bod 18 anotovaného rozhodnutí.

${ }^{176}$ Bod 36 anotovaného rozhodnutí.
} 
lní aplikace, na základě čehož došlo po akceptaci stran k přepravě na dohodnuté místo. Tuto činnost však společnost Lido Taxi považovala za protizákonnou, a proto se jako žalobce obrátila na Krajský soud v Brně s požadavkem na uložení předběžného opatření směřujícího $\mathrm{k}$ zákazu poskytování služeb společnosti Uber.

V původním řízení společnost Lido Taxi považovala počínání společnosti Uber za protizákonné a Krajský soud v Brně na základě předběžného opatření uložil společnosti Uber zdržet se provozování a zprostředkování taxislužby na území města Brna. Vrchní soud v Olomouci ale na základě odvolání Uberu neposoudil činnost poskytovatele jako provozování či zprostředkování taxislužby, když ji označil za jinou službu v oblasti dopravy. Navrhované předběžné opatření se tak stalo neúčinným.

Ústavní soud se zabýval opět obdobnými argumenty a posuzoval to, jakým způsobem nahlížet na služby poskytované společností Uber. Zdůraznil zejména, že shledal v úsudku Vrchního soudu pochybení. Právní argumentaci víceméně omezil jen na uvedení toho, že pokud se daná služba jeví jako taxislužba, pak taxislužbou bude. Nadto $k$ této argumentaci využil anglického přísloví a uvedl: "If it looks like a duck, swims like a duck, and quacks like a duck, then it probably is a duck". ${ }^{177}$ Pokud tedy Vrchní soud posoudil danou službu nikoli jako taxislužbu (a tedy nikoli jako potenciální konkurenci jiným poskytovatelům taxislužeb) jen z toho důvodu, že nebyly splněny některé zákonné požadavky, je taková úvaha špatná.

Ústavní soud na závěr konstatoval, že rozhodnutím Vrchního soudu došlo k porušení práva na svobodu podnikání a spravedlivý proces. ${ }^{178}$

Ústavní soud dlouhodobě prosazuje linii argumentace, ve které nerespektuje př́lišný formalismus př̀i výkladu práva. Tento poměrně krátký nález navazuje na sérii předchozích rozhodnutí ${ }^{179}$ a zabývá se otázkou, jak lze vnímat činnost společnosti Uber, která provozuje platformu, pomocí níž

\footnotetext{
177 Bod 16 anotovaného rozhodnutí.

178 Bod 21 anotovaného rozhodnutí.

179 Jedná se o usnesení Krajského soudu v Brně ze dne 7. 4. 2017, č. j. 18 Nc 9/2017-46, usnesení Vrchního soudu v Olomouci ze dne 22. 6. 2017, č. j. 7 Cmo 137 / 2017-341, usnesení Krajského soudu v Brně ze dne 17. 7. 2017, č. j. 18 NC 9/2017-377 a usnesení Vrchního soudu v Olomouci ze dne 27. 9. 2017, č. j. 7 Cmo 185/2017-507.
} 
dochází ke zprostředkovávání přepravy osob prostřednictvím v rámci platformy registrovaných řidičů.

Autor: PL

\section{PŘÍPUSTNOST POPLATKU ZA PŘENOS ELEKTŘINY VYROBENÉ V TUZEMSKU URČENÉ PRO VÝVOZ Z HLEDISKA VOLNÉHO POHYBU ZBOŽÍ}

Soud: $\quad$ Soudní dvůr Evropské unie

Věc: $\quad$ C-305/17 (FENS)

Datum: $\quad$ 6. 12.2018

Dostupnost: curia.europa.eu

Případ se týkal přípustnosti dočasného poplatku za přenos elektřiny vyrobené v tuzemsku určené pro vývoz, který stanovil slovenský Úrad pre regulaciu sietových odvetví a byl zaplacen v roce 2008 společností Korlea Invest a.s. (ta byla právní předchůdkyní žalobkyně, FENS spol. s r. o.), z hlediska článků 28 a 30 Smlouvy o fungování EU.

Žaloba byla v roce 2011 zamítnuta první instancí, ale v roce 2012 vrácena Krajským súdem v Bratislavě k opakovanému projednání. Okresní súd Bratislava II podal v roce 2017 předběžné otázky k SDEU ohledně slučitelnosti předmětného poplatku se zásadami volného pohybu zboží dle SFEU. $^{180}$

V řízení se vyjádřila nizozemská a slovenská vláda, obě ve smyslu aplikace sekundárního práva (směrnice 2003/54 či směrnice 2005/89) v souladu s předností posouzení souladu s provedenou formou harmonizace. ${ }^{181}$ Soudní dvůr však shledal provedenou harmonizaci za neúplnou, ${ }^{182}$ a tudíž dovodil potřebu provedení výkladu článků 28 a 30 SFEU. ${ }^{183}$

\footnotetext{
${ }^{180}$ Body 14-16 anotovaného rozhodnutí.

${ }^{181}$ Body 19-22 anotovaného rozhodnutí.

${ }^{182}$ Úplná harmonizace by vedla k posouzení souladu s harmonizačním předpisem namísto primárního práva (viz rozsudek SDEU ve věci C-573/12 ze dne 1. 7. 2014, Alands Vindkraft, bod 57).

${ }^{183}$ Body 24-27 anotovaného rozhodnutí.
} 
Soud následně při své analýze postupoval systematicky od posouzení existence poplatku s účinkem rovnocenným clu $\mathrm{k}$ případnému odůvodnění poplatku na základě výjimky. Pro určení existence poplatku s účinkem rovnocenným clu postačí (i) identifikace finanční zátěže, kterou jednostranně uložil členský stát, ${ }^{184}$ přičemž účel poplatku je irrelevantní; ${ }^{185}$ (ii) splnění kritéria výpočtu poplatku na základě přenesených kilowatthodin, čímž se jedná o poplatek na zboží ve smyslu unijního práva; ${ }^{186}$ (iii) zatížení tímto poplatkem $\mathrm{v}$ důsledku překročení hranice ${ }^{187} \mathrm{a}$ (iv) absence odůvodnění poplatku povinnostmi vyplývajícími z unijního práva. ${ }^{188}$ Tyto podmínky byly naplněny, jedná se tedy o poplatek s účinkem rovnocenným clu, přičemž tato kvalifikace platí jak pro elektřinu vyvezenou do zemí EU, tak do třetích zemí. ${ }^{189}$ Ve vztahu k odůvodnění výjimky z režimu článku 28 SFEU Soudní dvůr uvedl, že článek má obecnou a absolutní povahu a nestanoví žádnou výjimku. ${ }^{190} \mathrm{Z}$ hlediska unijního práva a zásady volného pohybu zboží tedy předmětný poplatek nebylo a není možné odůvodnit.

Soudní dvůr uzavřel, že články 28 a 30 SFEU brání členským státům v uložení poplatku za vývoz elektřiny do jiného členského státu či třetí země, pokud tato elektřina byla vyrobena v tuzemsku.

Autor: FK

Toto dílo lze užít v souladu s licenčními podmínkami Creative Commons BY-SA 4.0 International (http://creativecommons.org/licenses/by-sa/4.0/legalcode).

${ }^{184}$ Bod 29 anotovaného rozhodnutí s odkazem na rozsudek SDEU ve věci C-39/17 ze dne 14 . 6. 2018, Lubrizol France, bod 24.

185 Bod 33 anotovaného rozhodnutí s odkazem na rozsudek SDEU ve spojených věcech C441/98 a C-442/98 ze dne 21. 9. 2000, Michailidis, bod 14.

${ }^{186}$ Bod 34 anotovaného rozhodnutí s odkazem na rozsudek SDEU ve věci C-206/06 ze dne 17. 7. 2008, Essent Netwerk Noord a další, body 43 a 44.

${ }^{187}$ Body 36-41 anotovaného rozhodnutí s odkazem na rozsudek SDEU ve věci C-254/13 ze dne 2. 10. 2014, Orgacom, bod 28.

188 Body 42-44 anotovaného rozhodnutí.

189 Body 48-51 anotovaného rozhodnutí s odkazem na rozsudek SDEU ve věci C-36/94 ze dne 26. 10. 1995, Siesse, bod 17.

190 Bod 53 anotovaného rozhodnutí s odkazem na rozsudek SDEU ve spojených věcech C441/98 a C-442/98 ze dne 21. 9. 2000, Michailidis, bod 14. 